\title{
吸収式冷凍機におけるモリブデン酸塩濃度の 電気化学的評価*
}

\author{
八代 仁 **, 畠山裕起也**, 稲部 英則***, 関口恭一***, \\ 菱沼崇 ${ }^{\dagger}$, 伊藤雅彦 ${ }^{\dagger}$, 大中紀之 ${ }^{\dagger}$ \\ ** 岩手大学大学院 工学研究科応用化学・生命工学専攻 \\ *** 株式会社日立ビスシステム \\ 日立協和エンジニアリング株式会社
}

\section{Electrochemical Evaluation of Concentration of Molybdate in Absorption Refrigeration Systems*}

\author{
Hitoshi Yashiro**, Yukiya Hatakeyama**, Hidenori Inabe***, Kyouichi Sekiguchi***, \\ Takashi Hishinuma $^{\dagger}$, Masahiko Itoh $^{\dagger}$ and Noriyuki Ohnaka ${ }^{\dagger}$ \\ ** Department of Chemistry and Bioengineering, Graduate School of Engineering, Iwate University \\ *** Hitachi Building Systems Co., Ltd. \\ $\dagger$ Hitachi Kyowa Engineering Co., Ltd.
}

\begin{abstract}
In absorption refrigeration systems, it is necessary to maintain adequate concentration of inhibitor, especially that of molybdate, in an absorbent, i.e. concentrated $\mathrm{LiBr}$ solution, to keep the constructive materials free from corrosion damage. In order to propose an alternative to the current management method based on chemical analysis, electrochemical approach has been introduced for in situ analysis of molybdate in an absorbent in this study. Molybdate ions are successfully reduced on a glassy carbon electrode to give cathodic current which clearly depends on the concentration of molybdate. Because the cathodic polarization causes deposition of molybdenum (IV) oxide, successive anodic polarization is effective to quantify the amount of the deposits. Based on the redox phenomena of molybdenum species on a glassy carbon electrode as demonstrated in this study, the electrochemical technique can be applied to the practical management of adsorbent.
\end{abstract}

Key words : absorption refrigeration systems, lithium bromide, molybdate, electrochemical monitoring

1. 緒

$\overline{\overline{\overline{⿳ 亠 口}}}$

吸収式冷凍機は濃厚な $\mathrm{LiBr}$ 水溶液が著しく低い蒸気圧 を示すことを利用し, 蒸発器内の水の蒸発 (吸熱) と, 吸収器内の濃厚 $\mathrm{LiBr}$ 水溶液による水蒸気の吸収 (発熱) を通して，それぞれ冷温水を得る装置である. 吸収器で 希釈された $\mathrm{LiBr}$ 水溶液は再生器で加熱濃縮され, その最 高温度は約 $433 \mathrm{~K}$ に達する。再生器の熱源には通常都市 ガスが用いられるが, 燃料電池の廃熱なども利用可能な ことから，いわゆるコジェネレーションシステムとして の活用も期待されている. 吸収式冷凍機を構成する主材 料は炭素鋼であり，それ自体の耐食性が高くないことか ら，腐食抑制剤の添加が不可欠である1)-4)。高温濃厚 $\mathrm{LiBr}$ 水溶液中における炭素鋼の腐食とその抑制につい て，過去に多くの研究が行われた5)-10) 結果，アルカリ $(\mathrm{LiOH})$ とモリブデン酸塩 $\left(\mathrm{Li}_{2} \mathrm{MoO}_{4}\right)$ の併用が広く行わ れるようになった ${ }^{11)-16)}$ 。ただし濃厚 $\mathrm{LiBr}$ 水溶液中にお ける $\mathrm{Li}_{2} \mathrm{MoO}_{4}$ の溶解度は比較的限られており, 特に吸収 器のような低温部でも沈殿が生じない濃度（約 $3 \times 10^{-3}$

* 第 58 回材料と環境討論会 (名古屋, 2011 年) で発表

** T 020-8551 岩手県盛岡市上田 4-3-5 (4-3-5, Ueda, Morioka, 0208551 Japan)

*** ７101-8941 東京都千代田区神田美土代町 7 (7, Kanda-Mitoshirocho, Chiyoda-ku,Tokyo, 101-8941 Japan)

7317-0072 日立市弁天町 3-10-2 (3-10-2, Benten-cho, Hitachi, 317-0072 Japan) $\left.\mathrm{mol} \mathrm{kg}{ }^{-1}-\mathrm{H}_{2} \mathrm{O}\right)$ が添加の上限となっている.モリブデン 酸イオンは炭素鋼に対して不働態化剂として作用し, 自 らは還元されて $\mathrm{MoO}_{x}(x: 2 \sim 3)$ となって, マグネタイ 卜層の外側に付着する ${ }^{16), 17)}$. 従って吸収式冷凍機の運転 時間とともに徐々にではあるがその濃度の減少が避けら れない。このため, 吸収式冷凍機の運転においては, 吸 収液中のモリブデン酸塩濃度の管理が不可欠となってい る. 現在吸収液中のモリブデン酸塩濃度は, 吸収液のサ ンプリングとラボにおける化学分析によって管理されて いるが，これをその場で評価できればメンテナンスの効 率が向上すると期待される。 そこで, 吸収液中に適当な 電極を挿入し, 電気化学的手法を用いてモリブデン酸塩 濃度に応答する信号が得られないかを検討した結果，グ ラッシーカーボン電極を使用したときに望ましい結果が 得られることがわかった。本論文では吸収液中における モリブデン酸イオンの電気化学的挙動について, グラッ シーカーボン電極を用いて検討した結果を報告する。

\section{2. 実 験 方 法}

\section{1 作 用 電 極}

グラッシーカーボン（東海カーボン株式会社製 $\phi 3$ mm）をPTFE 熱収縮管で被覆した。先端の電極部 $\left(0.071 \mathrm{~cm}^{2}\right)$ をエメリー紙＃6/0 番まで研磨した後, アセ トン中で超音波洗浄して実験に用いた. 


\section{2 溶 液}

$\mathrm{LiBr} \cdot \mathrm{H}_{2} \mathrm{O}, \mathrm{LiOH} \cdot \mathrm{H}_{2} \mathrm{O}$ および $\mathrm{Li}_{2} \mathrm{MoO}_{4}$ (それぞれ和光純 薬製)を混合し, 重量モル濃度 $\left(\mathrm{mol} \mathrm{kg} \mathrm{kg}^{-1}-\mathrm{H}_{2} \mathrm{O}\right.$, 以下 $\mathrm{H}_{2} \mathrm{O}$ は省略）ベースで所定濃度の水溶液を調製した。 $\mathrm{LiBr}$ は $17.3 \mathrm{~mol} \mathrm{~kg}{ }^{-1}, \mathrm{LiOH}$ は $1 \times 10^{-1} \mathrm{~mol} \mathrm{~kg}^{-1}, \mathrm{Li}_{2} \mathrm{MoO}_{4}$ は $0 \sim 3 \times 10^{-3} \mathrm{~mol} \mathrm{~kg}^{-1}$ とした。一部の溶液中には $\mathrm{LiNO}_{3}$ あるいは $\mathrm{CuBr}_{2}$ を添加し，それらの影響を調べた。 実機におけるモリブデン酸塩濃度のモニタリングは，装 置内の最低温部 (吸収器) で行うことを想定し, 溶液温 度はすべて $313 \mathrm{~K}$ とした。また試験中溶液には常に $\mathrm{Ar}$ を $100 \mathrm{~cm}^{3} \mathrm{~min}^{-1}$ で通気させた。

\section{3 装置}

セルは PTFE 製で内容積はおよそ $200 \mathrm{~cm}^{3}$ である。二 重液絡構造の $\mathrm{Ag} / \mathrm{AgCl} / \mathrm{KCl}$ (sat.) 参照電極を, セル内の 試験溶液と液絡を介して導通を保ったまま室温まで冷や した $17.3 \mathrm{~mol} \mathrm{~kg}^{-1} \mathrm{LiBr}$ 水溶液中に挿入した. 本論文で は，この外部参照電極を用いて測定した電位をそのまま 表示した。対極には Pt 板を用いた。

\section{4 操 作}

以下のような電気化学的操作を行った１）作用極の電 位を自然電位から $1 \mathrm{mV} \mathrm{s}^{-1}$ の走査速度でカソード方向 に-1.4 V まで掃引してモリブデン酸イオンの還元挙動を 観察後，ただちにアノード方向に同じ走査速度で掃引し， 電極に析出した還元生成物の酸化的溶出挙動を観察し た. 2) 作用極に対して $-100 \mu \mathrm{A} \mathrm{cm}^{-2}$ の定電流を印加し, 電位の経時変化を測定した。 3）作用極を-1.25 V に 180 $\mathrm{s}$ 間分極してカソード電流の経時変化を測定した後，引 き続き $-0.45 \mathrm{~V}$ にステップ分極して $120 \mathrm{~s}$ 間アノード電 流を測定した。

\section{3. 結果および考察}

\section{1 動電位分極}

Fig. 1(a)に $313 \mathrm{~K}$ の $17.3 \mathrm{~mol} \mathrm{~kg}^{-1} \mathrm{LiBr}+1 \times 10^{-1} \mathrm{~mol}$ $\mathrm{kg}^{-1} \mathrm{LiOH}+\left(0 \sim 3 \times 10^{-3}\right) \mathrm{mol} \mathrm{kg}^{-1} \mathrm{Li}_{2} \mathrm{MoO}_{4}$ 溶液中, グ
ラッシーカーボン電極を作用電極として測定した往復分 極曲線のうち, 最初のカソード分極曲線を示す. 自然電 位は溶液中のモリブデン酸塩濃度にかかわらず約 +0.05 $\mathrm{V}$ であった。この電位から約 $-1.2 \mathrm{~V}$ までの掃引中カソー ド電流密度に差はみられないが， $-1.2 \mathrm{~V}$ より卑な電位で は電流密度に差が現れ, $\mathrm{Li}_{2} \mathrm{MoO}_{4}$ 濃度が高いほど電流密 度が高くなった。この電流密度の増加はモリブデン酸イ オンの還元反応によるグラッシーカーボン上への $\mathrm{MoO}_{2}$ の析出 (式 (1)) と, その析出によって加速された水素発 生 (式 (2)) によると考えられる。

$$
\begin{aligned}
& \mathrm{MoO}_{4}{ }^{2-}+2 \mathrm{e}^{-}+\mathrm{H}_{2} \mathrm{O} \rightarrow \mathrm{MoO}_{2}+2 \mathrm{OH}^{-} \\
& 2 \mathrm{H}_{2} \mathrm{O}+2 \mathrm{e}^{-} \rightarrow \mathrm{H}_{2}+2 \mathrm{OH}^{-}
\end{aligned}
$$

水素発生の根拠については後で何度か触れる。式 (1) に関しては, 長時間カソード分極後の電極上に黒い導電 性粉末が生成すること，これまでの研究結果から，この 溶液中に浸漬した炭素鋼上に生成する皮膜の外層が $\mathrm{MoO}_{2}$ と同定されており ${ }^{13)}, \mathrm{MoO}_{2}$ 薄膜が生成している と推定した. しかし, 後述するように一部は不定比の低 級酸化物, あるいは金属モリブデンが生成している可能 性もある。

Fig. 1(b)は, Fig. 1(a)に示したカソード分極後, 掃引 方向を反転させ， $+0.2 \mathrm{~V}$ まで掃引したときのアノード分 極曲線を示す．アノード方向に掃引しているにもかかわ らず，Fig. 1(a)の場合に比べて，最初のカソード電流が 大きくなっている。これは前述したように $\mathrm{MoO}_{2}$ の析出 したグラッシーカーボン電極のほうが, 裸の状態に比べ て水素加電圧が小さくなるためと考えられる. $\mathrm{Li}_{2} \mathrm{MoO}_{4}$ 濃度が $10^{-3} \mathrm{~mol} \mathrm{~kg}^{-1}$ 以上の場合, 約 $-0.45 \mathrm{~V}$ に明暸な アノードピークが認められた。このピークは式(1)の逆 反応，すなわちカソード分極によって析出した $\mathrm{MoO}_{2}$ の アノード溶解であると考えられる。なお－ $0.23 \mathrm{~V}$ にもア ノードピークが観察されるが詳細はまだわかっていな い.この溶液中で金属モリブデンをアノード分極する と $-0.2 \mathrm{~V}$ 付近からアノード電流が増加することから, 一 部金属モリブデンまで還元が進み，それがより大きな過 電圧を伴ってこの電位で酸化されていた可能性も考えら れる。

このように，グラッシーカー ボン電極を作用極として適当な 分極操作を行うことで $\mathrm{Li}_{2} \mathrm{MoO}_{4}$ 濃度に依存する電流が得られる ことが示された。

\section{2 定電流分極}

Fig. 1 の結果に基づくと, グ ラッシーカーボン電極に例え ばー $100 \mu \mathrm{A} \mathrm{cm}^{-2}$ の定電流を印 加した場合，電極電位は溶液中 のモリブデン酸塩濃度によって 変化することが予想される. 実 際にー $100 \mu \mathrm{A} \mathrm{cm}^{-2}$ を印加した ときの電位の経時変化を調べた 結果を Fig. 2 に示す. 溶液中に モリブデン酸塩が含まれる場 合, 最初の約 $40 \mathrm{~s}$ 間は電位が 単調に卑化したが, その後電位

Fig. 1 (a) Cathodic polarization curves for a glassy carbon electrode in $17.3 \mathrm{~mol} \mathrm{~kg}{ }^{-1} \mathrm{LiBr}+$ $1 \times 10^{-1} \mathrm{~mol} \mathrm{~kg}^{-1} \mathrm{LiOH}$ with different concentrations of $\mathrm{Li}_{2} \mathrm{MoO}_{4}$ at $313 \mathrm{~K}$ with a scan rate of $1 \mathrm{mV} \mathrm{s}^{-1}$. (b) Successive anodic polarization curves from $-1.4 \mathrm{~V}$. 


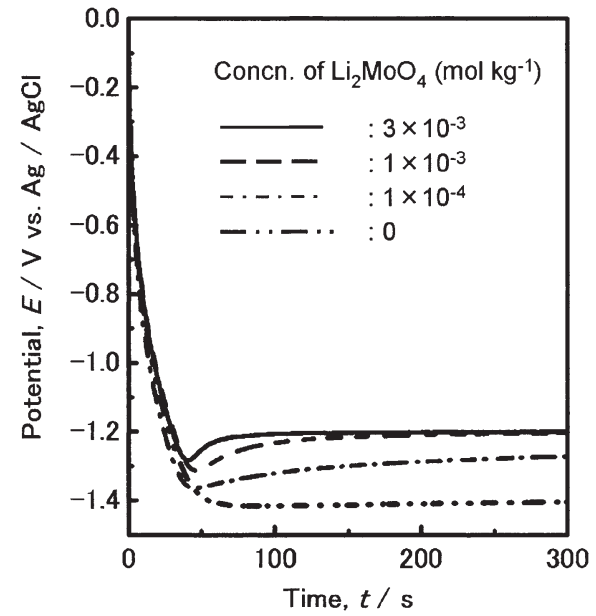

Fig. 2 Time-variation of potential of a glassy carbon electrode in $17.3 \mathrm{~mol} \mathrm{~kg}{ }^{-1} \mathrm{LiBr}+1 \times 10^{-1} \mathrm{~mol} \mathrm{~kg}{ }^{-1} \mathrm{LiOH}$ with different concentrations of $\mathrm{Li}_{2} \mathrm{MoO}_{4}$ under cathodic applied current density of $100 \mu \mathrm{A} \mathrm{cm}^{-2}$ at $313 \mathrm{~K}$.

は貴に転じ，約ー $1.2 \mathrm{~V}$ に漸近した。一方溶液中にモリブ デン酸塩が全く存在しない場合は, $-1.42 \mathrm{~V}$ 付近で停滞 したままであった。これらの現象は以下のように説明で きる.すなわち, 溶液中にモリブデン酸塩が含まれる場 合, $-100 \mu \mathrm{A} \mathrm{cm}^{-2}$ の定電流は，モリブデン酸イオンの 還元反応と水素発生反応によって担われるが，その大き さは水素発生の電流が支配的である。この電流密度にお ける水素発生の定常電位は, 裸のグラッシーカーボン上 では- $1.42 \mathrm{~V}$ であるが， $\mathrm{MoO}_{2}$ が十分析出した電極上で は，水素加電圧が小さくなるため約 $-1.2 \mathrm{~V}$ である．溶液 中のモリブデン酸塩濃度が高いほど早く電位が $-1.2 \mathrm{~V}$ に 近づいたのは，溶液中のモリブデン酸塩濃度が高いほど グラッシーカーボン電極が早く $\mathrm{MoO}_{2}$ で覆われたためと 推定される. したがってこれらの過渡変化を捉えること で溶液中のモリブデン酸塩濃度を評価することが可能に なる. 一例として, 定電流印加 $60 \mathrm{~s}$ 後と $100 \mathrm{~s}$ 後の電位 を溶液中のモリブデン酸塩濃度の関数として整理したグ ラフを Fig. 3 に示す. いずれもモリブデン酸塩濃度が高 くなるほど電位は貴になるが，分極後の時間が長く経過 するほど高濃度側での電位差が小さくなる。これは前述 したようにいずれのモリブデン酸塩濃度でもやがてはグ ラッシーカーボン電極が $\mathrm{MoO}_{2}$ で覆われていくためであ る。しかしモリブデン酸塩が全く存在しなければ長時間 測定を続けても電位差（約 $200 \mathrm{mV}$ ) はなくならない。一 方モリブデン酸塩濃度が比較的高い場合は，50～60 秒後 の電位差を利用する方が濃度差の検出に有利といえる.

\section{3 定電位分極}

モリブデン酸塩濃度が異なるいくつかの溶液中でグラ ッシーカーボン電極を $-1.25 \mathrm{~V}$ にじらく分極してカソ ード電流の経時変化を観察するとともに, 引き続き析出 した $\mathrm{MoO}_{2}$ を酸化的に溶出させることを目的として -0.45V に分極し，アノード電流の経時変化を測定した. この結果を Fig. 4 に示す. 溶液中にモリブデン酸塩が含 まれる場合, 最初のカソード電流は一旦減少した後増加 に転じ，モリブデン酸塩濃度が最も高い $3 \times 10^{-3} \mathrm{~mol}$ $\mathrm{kg}^{-1}$ の場合, 約 $100 \mathrm{~s}$ 後には約 $8 \mathrm{~mA} \mathrm{~cm}^{-2}$ (カソード) の

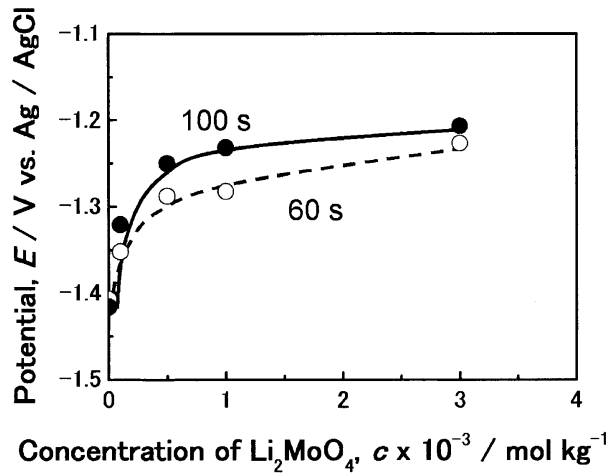

Fig. 3 The relation between the potentials reached and concentration of $\mathrm{Li}_{2} \mathrm{MoO}_{4}$ under cathodic applied current density of $100 \mu \mathrm{A} \mathrm{cm}^{-2}$ on the glassy carbon electrode in $17.3 \mathrm{~mol}$ $\mathrm{kg}^{-1} \mathrm{LiBr}+1 \times 10^{-1} \mathrm{~mol} \mathrm{~kg}^{-1} \mathrm{LiOH}$ solution at $313 \mathrm{~K}$.

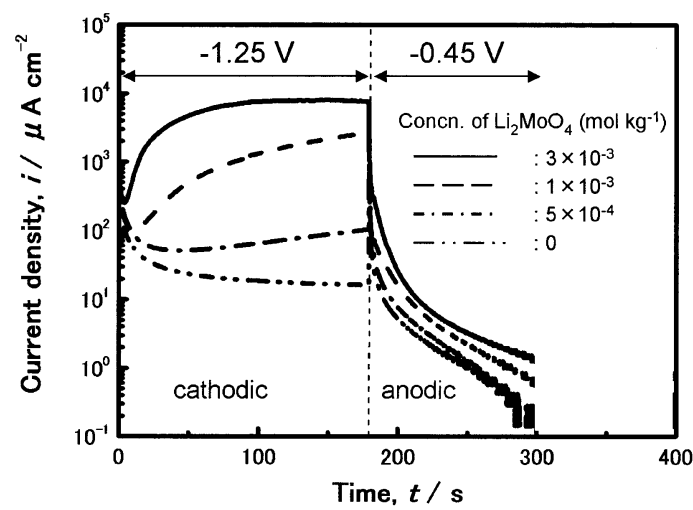

Fig. 4 Time-variation of the current density on a glassy carbon electrode in $17.3 \mathrm{~mol} \mathrm{~kg}{ }^{-1} \mathrm{LiBr}+1 \times 10^{-1} \mathrm{~mol} \mathrm{~kg} \mathrm{~kg}^{-1} \mathrm{LiOH}$ with different concentrations of $\mathrm{Li}_{2} \mathrm{MoO}_{4}$ under applied potentials of $-1.25 \mathrm{~V}$ (up to $180 \mathrm{~s}$ ) and $-0.45 \mathrm{~V}$ (after $180 \mathrm{~s})$ at $313 \mathrm{~K}$

電流密度で飽和となった。モリブデン酸塩濃度がこれよ

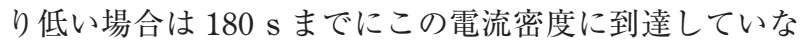
いが，電極表面における $\mathrm{MoO}_{2}$ の析出が続けば，やがて 同程度の電流密度に達すると考えられる。すなわち測定 時間をあまり長くすると, カソード電気量の相対的な差 は小さくなっていくと考えられることから，本実験条件 下では $180 \mathrm{~s}$ が適当な時間と結論された。 $180 \mathrm{~s}$ 間のカソ ード分極に引き続き $-0.45 \mathrm{~V}$ に分極すると，直ちにアノ ード電流が観察され単調に減衰していった。 $120 \mathrm{~s}$ 間で 電流は 2 桁以上低下したことから，ここで分極操作を打 ち切った.これらの 2 つのステップの分極を通して電極 に流れたカソード電気量とアノード電気量を, 溶液中の $\mathrm{Li}_{2} \mathrm{MoO}_{4}$ 濃度の関数として整理すると Fig. 5 が得られた。 いずれも電気量は $\mathrm{Li}_{2} \mathrm{MoO}_{4}$ 濃度に対してほぼ直線的に変 化した。したがって，これらの関係を利用することで， 溶液中の $\mathrm{Li}_{2} \mathrm{MoO}_{4}$ 濃度が評価可能であるといえる.なお, Fig. $5(\mathrm{a})$ と (b) を比較するとカソード電気量に対してア ノード電気量は $1 \%$ に満たないことがわかる.このこ とは, Fig. 4 におけるカソード電流のほとんどがモリブ デン酸イオンの還元（式(1)) ではなく, 水素発生（式 (2)）の電流であることを示している. Fig. 5(a)において カソード電気量が $\mathrm{Li}_{2} \mathrm{MoO}_{4}$ 濃度に依存する理由は, 水素 発生の電流がブラッシーカーボン上に析出した $\mathrm{MoO}_{2}$ の 


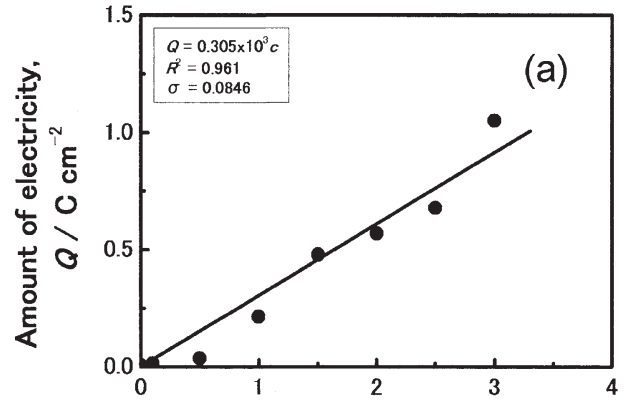

Concentration of $\mathrm{Li}_{2} \mathrm{MoO}_{4}, c \times 10^{3} / \mathrm{mol} \mathrm{kg}^{-1}$

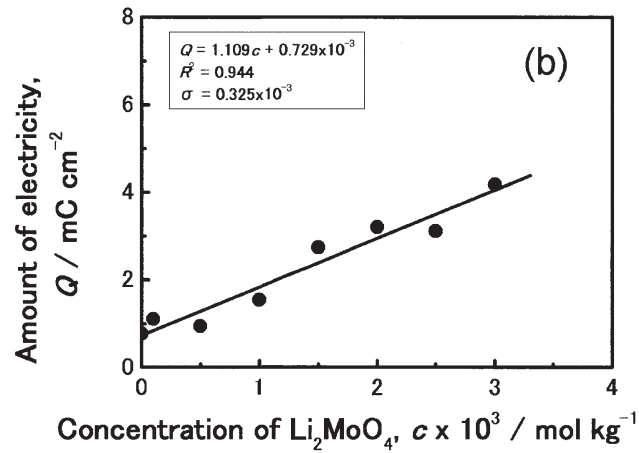

Fig. 5 (a) The relation between concentration of $\mathrm{Li}_{2} \mathrm{MoO}_{4}$ in 17.3 mol kg-1 $\mathrm{LiBr}+1 \times 10^{-1} \mathrm{~mol} \mathrm{~kg}^{-1} \mathrm{LiOH}$ solution and the amount of electricity passed during (a) the initial cathodic polarization at $-1.25 \mathrm{~V}$ for $180 \mathrm{~s}$ and $(\mathrm{b})$ the successive anodic polarization at $-0.45 \mathrm{~V}$ for $120 \mathrm{~s}$.

量 (被覆率) に強く依存しているためである. Fig. 4 にお いて水素発生電流密度が飽和に達した $3 \times 10^{-3} \mathrm{~mol} \mathrm{~kg}^{-1}$ の場合, 析出した $\mathrm{MoO}_{2}$ の酸化に対するアノード電気量 は約 $4 \mathrm{mC} \mathrm{cm}^{-2}$ であった。これは平均すると約 $4 \mathrm{~nm}$ の 厚さに相当する。

\section{4 $\mathrm{LiNO}_{3}$ および $\mathrm{CuBr}_{2}$ の影響}

吸収液中に含まれうる化学種のうち，少なくともモリ ブデン酸イオンより酸化力の高い物質は, グラッシーカ ーボン電極のカソード分極挙動 に影響を与える可能性がある。 このような観点から, $\mathrm{LiNO}_{3}$ お よび $\mathrm{CuBr}_{2}$ の影響を検討した。 $\mathrm{LiNO}_{3}$ は $\mathrm{Li}_{2} \mathrm{MoO}_{4}$ の穏やかな酸 化力を補って炭素鋼の初期不働 態化を促進するため，特に運転 開始時に添加される15),17) が，時 間とともに消失することがわか っている. $17.3 \mathrm{~mol} \mathrm{~kg}^{-1} \mathrm{LiBr}+$ $1 \times 10^{-1} \mathrm{~mol} \mathrm{~kg}^{-1} \mathrm{LiOH}+(0$ or $\left.3 \times 10^{-3} \mathrm{~mol} \mathrm{~kg}^{-1}\right) \mathrm{Li}_{2} \mathrm{MoO}_{4}+(0$ or $\left.1 \times 10^{-2} \mathrm{~mol} \mathrm{~kg}^{-1}\right) \mathrm{LiNO}_{3}$ 水溶 液中におけるグラッシーカーボ ン電極の往復分極曲線を Fig. 6 に示す。 $\mathrm{Li}_{2} \mathrm{MoO}_{4}$ 濃度が $3 \times$ $10^{-3} \mathrm{~mol} \mathrm{~kg}^{-1}$ の場合 (Group A)，カソード分極において電流 密度に対しては全く影響がみら れない.引き続きアノード分極
を行うと， $-0.45 \mathrm{~V}$ に全く同じ大きさのアノードピーク が観察されたことから, 式 (2)による $\mathrm{MoO}_{2}$ の析出とそ の再酸化に対しても, $\mathrm{LiNO}_{3}$ は全く影響しないといえる. ただし $-0.2 \mathrm{~V}$ 付近のピークの差の理由はまだ不明であ る。一方, $\mathrm{Li}_{2} \mathrm{MoO}_{4}$ が存在しない場合 (Group B) は水素 発生電流が非常に小さくなるため, 硝酸イオンが存在す る場合にその還元反応に対応すると考えられるカソード 電流が観察された。この場合でもアノード分極時に析出 物の再酸化に対応する電流が全く生じないことから，モ リブデン酸塩が存在しないことを知ることができる.

吸収式冷凍機では熱交換器に銅を含む材料を用いてい ることから，吸収液中に銅イオン種が含まれる場合があ る ${ }^{18)}$. Fig. 7 に示す結果から, $\mathrm{Li}_{2} \mathrm{MoO}_{4}$ 濃度が $3 \times 10^{-3}$ $\mathrm{mol} \mathrm{kg} \mathrm{kg}^{-1}$ の場合 (Group A) には少なくとも $1 \times 10^{-4} \mathrm{~mol}$ $\mathrm{kg}^{-1}$ 以下の銅（II）イオンは本測定によるモリブデン酸 イオンの検出に全く影響しないと結論された。一方， $\mathrm{Li}_{2} \mathrm{MoO}_{4}$ が存在しない場合 (Group B) にはカソード分極 時にわずかながら銅 (II) イオンの還元に対応するカソー ド電流が観察された. 硝酸イオンと異なり, 銅 (II) イオ ンはグラッシーカーボン上に還元析出することから，ア ノード分極時にも電流ピークを与える。この電流ピーク の電位は $\mathrm{MoO}_{2}$ の酸化電位と非常に近い. 銅は $\mathrm{MoO}_{2}$ に 比べて水素加電圧が大きく, 析出しても水素発生をほと んど加速しない.したがってカソード分極時の電流が小 さいのにアノード電流ピークが観察される場合は，銅の 析出を疑う必要があるかもしれない。なお, 銅イオンの 混入は，それ自体が吸収式冷凍機にとって好ましい現象 ではないので，これを同時に評価ができれば，本電気化 学的アプローチの価值がさらに高まる可能性もある.

以上の結果は, グラッシーカーボン電極を用いること により，吸収式冷凍機の吸収液中でモリブデン酸イオン を還元させ，あるいはその析出物を再び酸化させること によって，電気化学的にモリブデン酸イオン濃度をその 場評価できる可能性を示したものである. 今後実用化に 向けて, 連続的なモニタリング法として最適化を図る予 定である。
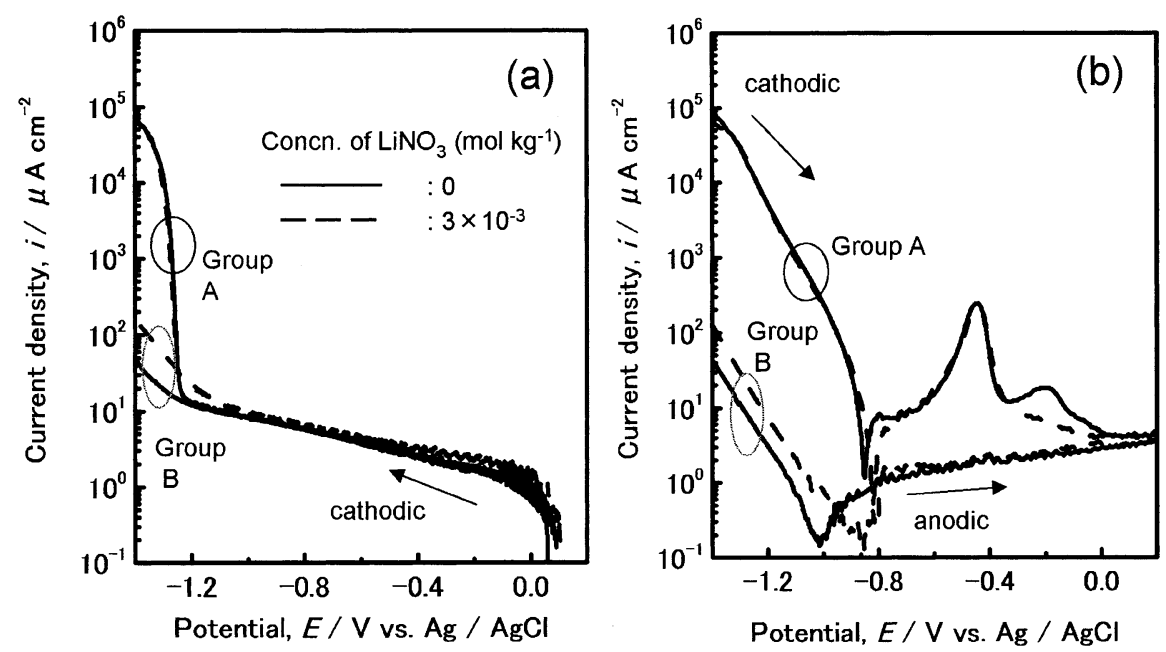

Fig. 6 Effect of $\mathrm{LiNO}_{3}$ on (a) cathodic polarization curves for a glassy carbon electrode in 17.3 mol kg-1 $\mathrm{LiBr}+1 \times 10^{-1} \mathrm{~mol} \mathrm{~kg}{ }^{-1} \mathrm{LiOH}$ with different concentrations of $\mathrm{Li}_{2} \mathrm{MoO}_{4}$ (Group A : $3 \times 10^{-3}$, Group B : $0 \mathrm{~mol} \mathrm{~kg}^{-1}$ ) at $313 \mathrm{~K}$ and (b) successive anodic polarization curves from $-1.4 \mathrm{~V}$. Scan rate $: 1 \mathrm{mV} \mathrm{s}^{-1}$. 

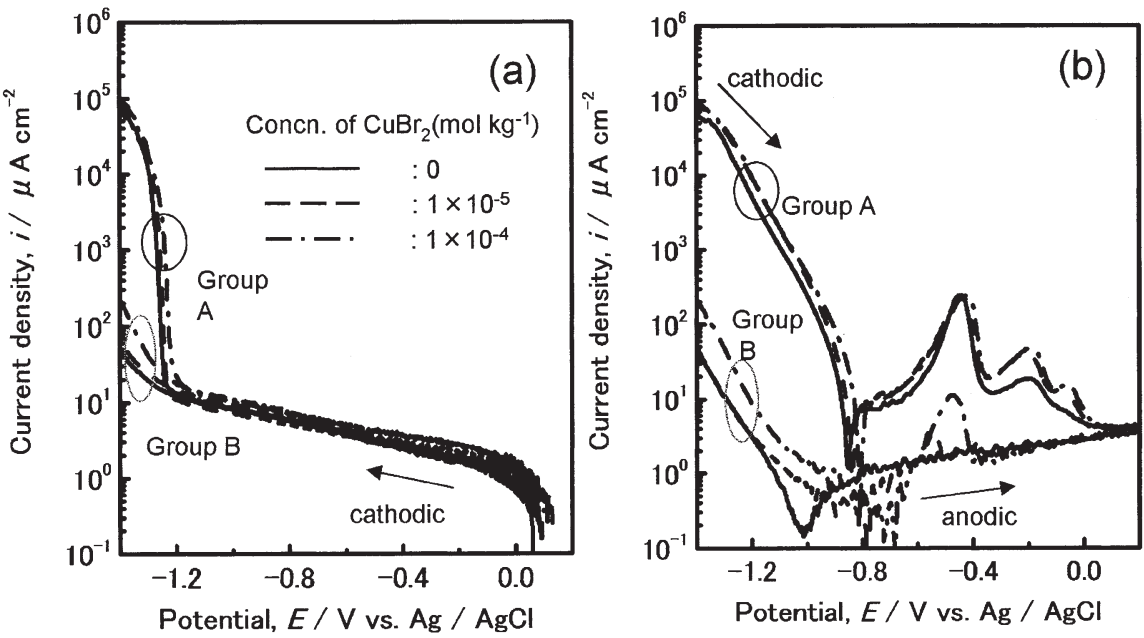

Fig. 7 Effect of $\mathrm{CuBr}_{2}$ on (a) cathodic polarization curves for a glassy carbon electrode in 17.3 mol kg ${ }^{-1} \mathrm{LiBr}+1 \times 10^{-1} \mathrm{~mol} \mathrm{~kg}{ }^{-1} \mathrm{LiOH}$ with different concentrations of $\mathrm{Li}_{2} \mathrm{MoO}_{4}$ (Group A : $3 \times 10^{-3}$, Group B : $0 \mathrm{~mol} \mathrm{~kg}^{-1}$ ) at $313 \mathrm{~K}$ and (b) successive anodic polarization curves from $-1.4 \mathrm{~V}$. Scan rate $: 1 \mathrm{mV} \mathrm{s}^{-1}$.

\section{4. 結}

論

吸収式冷凍機の吸収液中におけるモリブデン酸塩濃度 を電気化学的に検出する方法を提案することを目的とし て, $313 \mathrm{~K}$ の $17.3 \mathrm{~mol} \mathrm{~kg}{ }^{-1} \mathrm{LiBr}+0.1 \mathrm{~mol} \mathrm{~kg}{ }^{-1} \mathrm{LiOH}$ 水溶 液中においてグラッシーカーボン電極の電気化学的挙動 に対する $\mathrm{Li}_{2} \mathrm{MoO}_{4}$ 濃度の影響を検討した結果，以下の結 論を得た。

1）動電位分極において，約 $-1.2 \mathrm{~V}$ より卑な電位で $\mathrm{MoO}_{2}$ の析出とそれによって加速される水素発生が生じ た。このとき流れるカソード電流は溶液中の $\mathrm{Li}_{2} \mathrm{MoO}_{4}$ 濃 度が高いほど大きくなった引引き続きアノード分極を行 うと, 析出した $\mathrm{MoO}_{2}$ は約 $-0.45 \mathrm{~V}$ で溶解し, これに対 応するアノード電流もまた $\mathrm{Li}_{2} \mathrm{MoO}_{4}$ 濃度に依存した。

2）グラッシーカーボン電極を定電流カソード分極し た場合，その過渡的な電極電位は溶液中の $\mathrm{Li}_{2} \mathrm{MoO}_{4}$ 濃度 が高いほど貴になった。

3） $-1.25 \mathrm{~V}$ で定電位分極した場合， $\mathrm{Li}_{2} \mathrm{MoO}_{4}$ の濃度 が高いほどカソード電気量は増加した。引き続き， -0.45 $\mathrm{V}$ に分極すると $\mathrm{Li}_{2} \mathrm{MoO}_{4}$ 濃度にほぼ比例するアノード電 気量が測定された。

4）吸収液中に $\mathrm{LiNO}_{3}$ または $\mathrm{CuBr}_{2}$ が存在しても，そ
の影響は非常に限定的で, 本法 による $\mathrm{Li}_{2} \mathrm{MoO}_{4}$ 濃度の評価には ほとんど影響を及ぼさない。

\section{謝辞}

本研究に協力いただいた本学 渡辺美和技術職員に感謝いたし ます。

\section{参 考 文 献}

1) K. Tanno, M. Itoh, M. Aizawa, K. Mabuchi and H. Yashiro, Zairyoto-Kankyo, 52, 236 (2003).

2) K. F. Dockus, R. H. Krueger and W. F. Rush, ASHRAE J., 4, 67 (1962)

3) K. Tanno, M Itoh, T. Takahashi, H. Yashiro and N. Kumagai, Corros. Sci., 34, 1441 (1993).

4) H. Yashiro, A. Sai, N. Kumagai, K. Tanno and K. Mabuchi, Zairyo-to-Kankyo, 48, 369 (1999).

5) Y. Umetsu, K. Tanno and M. Itoh, Boshoku-Gijutsu (Presently Zairyo-to-Kankyo), 29, 233 (1980).

6) K. Tanno, S. Saitoh, M. Itoh and A. Minato, Boshoku-Gijutsu (Presently Zairyo-to-Kankyo), 33, 516 (1984).

7) K. Tanno, S. Saitoh and M. Itoh, Boshoku-Gijutsu (Presently Zairyo-to-Kankyo) , 35, 455 (1986)

8) M. Itoh, K. Itoh. M. Izumiya and K. Tanno, Zairyo-toKankyo, 40, 163 (1991).

9) Y. Kojima and S. Tsujikawa, Zairyo-to-Kankyo, 47, 49 (1998).

10) Y. Kojima, S. Tsujikawa, Zairyo-to-Kankyo, 47, 117 (1998).

11) M. Itoh, A. Minato, M. Aizawa and K. Tanno, BoshokuGjjutsu (Presently Zairyo-to-Kankyo), 33, 504 (1984).

12) M. Itoh, M. Aizawa and K. Tanno, Boshoku-Gijutsu (Presently Zairyo-to-Kankyo), 36, 142 (1987)

13) M. Itoh, H. Midorikawa, M. Izumiya, M. Aizawa and K. Tanno, Boshoku-Gijutsu (Presently Zairyo-to-Kankyo), 39, 298 (1990).

14) K. Tanno, M Itoh, H. Sekiya, H. Yashiro and N. Kumagai, Corros. Sci., 34, 1453 (1993).

15) K. Mabuchi, T. Kikuchi, H. Midorikawa and M. Aizawa, Zairyo-to-Kankyo, 45, 526 (1996)

16) H. Yashiro, A. Sai, N. Kumagai, K. Tanno and K. Mabuchi, Zairyo-to-Kankyo, 49, 288 (2000).

17) H. Yashiro, M. Kawata, M. Itoh, K. Machizawa, K. Shimizu, Zairyo-to-Kankyo, 55, 549 (2006).

18) K. Machizawa, K. Takenaka, Y. Hirata, M. Nagao, N. Ohnaka, M. Itagaki, Zairyo-to-Kankyo, 55, 312 (2006).

(Manuscript received October 20, 2011; in final form January 30. 2012)

吸収式冷凍機では構造材を腐食させないように，吸収液すなわち濃厚 $\mathrm{LiBr}$ 水溶液中のインヒビター濃 度，とりわけモリブデン酸塩濃度を適切に管理することが必要である. 従来行われている化学分析に基づ く濃度管理法に代わる方法として, 本研究では吸収液中のモリブデン酸塩濃度を電気化学的にその場評価 する方法が検討された。グラッシーカーボン電極上においてモリブデン酸イオンが還元され，その濃度に 依存するカソード電流が得られた。カソード分極において酸化モリブデン (IV) が析出し，その量は引き 続きアノード分極を行うことで評価できる. 本研究で例示したいくつかの電気化学的手法を用いることに よって，グラッシーカーボン電極上でのモリブデン化学種の酸化還元挙動に基づいて，実際の吸収式冷凍 機中のモリブデン酸塩濃度をその場管理できると考えられる。

キーワード＼cjkstart吸収式冷凍機，臭化リチウム，モリブデン酸塩，電気化学的モニタリング 